\title{
An experimental study of English accent perception
}

Elena Shamina

Department of Phonetics, Saint Petersburg State University, Russia

https://doi.org/10.36505/ExLing-2016/07/0036/000295

\begin{abstract}
The study aims at proving the observation that in English oral speech perception, sociolinguistic evaluation prevails over personal one. The total of 10 speech samples by 2 native English speakers with no special phonetic or acting training imitating various English accents were evaluated by 26 native English speakers on a number of scales related to sociolinguistic and personal factors. When listening to the same persons speaking in different English language varieties the respondents ascribed to them very different social qualities, such as social class, education and occupation. The personality properties ascribed, such as character traits and age, are shown to depend on the social factors, associated with the accent.

Key words: sociolinguistics, perception, English accents, social and personal qualities
\end{abstract}

\section{Introduction: sociolinguistic experimental data}

Experimental studies have been used in sociolinguistics to demonstrate a consistent correspondence between pronunciation and social class in the English speaking societies (Wells 1982). They have shown that sociolinguistic evaluation is inherent in (at least English) speech perception and essentially depends on the sociolinguistic profile of the listener (Labov 1972), and that some varieties of English, including foreign accents, may be stigmatized (Coupland, Bishop 2007; Абрамова 2009). Validity of the social characteristics, such as socio-economic status, education, occupation, place of residence, ascribed to English speakers only on the basis of their pronunciation has been ascertained (Shamina 2011; Шамина 2012). Also, the data gathered from polls and questionnaires points to some informants having strong emotional reactions to certain accents.

\section{Material and procedure}

This particular study is undertaken in complete agreement with the previous research in the field of sociophonetics. It aims at proving the observation that in English oral speech perception, sociolinguistic evaluation prevails over personal one. The experimental procedure involved 2 native English speakers (both male and well-educated) who had no special phonetic or acting training but claimed that they could

ExLing 2016: Proceedings of $7^{\text {th }}$ Tutorial and Research Workshop on Experimental Linguistics, 27 June - 2 July 2016, Saint Petersburg, Russia 
imitate various accents supplying recordings of 11 - 25 seconds long on a neutral topic that had no relation to their social or personal characteristics. The varieties of English represented, except formal RP, were dialects of Manchester, Liverpool, Newcastle, Somerset, Yorkshire, West London (Hammersmith), Cockney, Southern Irish, (Southern) American English, as well as French English (defined as such by the speakers themselves). Respondents (26 native English speakers, both men and women in the age range of $21-64$, of different social status and speakers of different national and regional varieties of English) were contacted via Internet and asked to evaluate the speech samples on a number of scales related to sociolinguistic factors, such as social class, occupation, education, place of residence and also personal factors, such as age and personal qualities. Their answers were then analysed.

\section{Results and discussion \\ Perception of social properties}

As in the previous research into the matter (Shamina 2011), the respondents were rather accurate in placing the speech samples on the map of world Englishes. But what is of most interest here is that when listening to the same persons speaking in different English language varieties the listeners ascribed to them very different social characteristics. For example, when Speaker 2 spoke in Somerset dialect his social status was evaluated as upper class and upper middle class by almost half of the respondents, but when he spoke in Newcastle dialect his perceived social position dropped dramatically and he was thought of as a representative of the working class by more than a third of the respondents. The level of education ascribed to the speakers, too, was a function of the variety of English spoken. For instance, Speaker 1 was considered to be university-educated when speaking formal RP by $73 \%$ of the respondents, to have an intermediate kind of education when speaking Yorkshire dialect by $63 \%$ and Cockney by $50 \%$ of the respondents correspondingly, and to be uneducated when speaking Southern American English by 85\% of the participants. The figures, once again, prove that English accents have stigmatized social values.

Descriptions of occupation suggested by the respondents for the speakers, as should be expected, were closely connected to their social status and education. When the speaker was presumed to be from Southern Ireland and of working or lower middle class, he was supposed to have such jobs as "driver, driving instructor, pizza delivery person, technical support, call centre" and even "criminal". On the other hand, when a speech sample was recognized as coming from a middle class 
person with a university degree living in Somerset, the suggested job descriptions included "philosopher, lecturer, artist, researcher, writer", etc. Interestingly, when the respondents heard Speaker 1 imitating a foreign (French) accent they were more reticent in their social judgment and tended to place him in the middle of the social ladder (lower and upper middle class in $73 \%$ of the responses). They were also rather at a loss when defining his professional qualifications and mentioned, among others, such inconspicuous occupations as "traveler, poet, teacher, tourist agent, student".

\section{Perception of personal properties}

Furthermore, the personality properties ascribed to the speakers by the respondents, such as character traits or even age, may be shown to depend on the social factors, associated with the accent. The speakers' age was determined by their education and occupation (which in their turn were interrelated with the social class): the higher the education of the speaker presumably was, the older he was thought to be. The age of Speaker 1 varied from 20-30 years old (in $100 \%$ of the answers) as a not very well educated (88\%) working class member $(77 \%)$ speaking Northern English (Manchester) to 30-40 (70\%) or even $40-50(12 \%)$ as a university-educated $(73 \%)$ middle class $(85 \%)$ RP speaker. According to the respondents' opinion, there were no uneducated people in the age group of 50-60 years old.

Personality traits that the respondents had to choose from the list offered in their answer sheets to describe the speakers (in the form of 8 pairs of adjectives with contrastive meanings, such as "industrious - lazy" or "introvert - extravert"), varied greatly for each speaker. In ascribing them, the respondents obviously relied not on the quality of the speakers' voices (individual timbre), but on the associations their accents have in the present day English speaking societies. The same speaker, in the opinion of the listeners, sounded responsible, considerate and generous when speaking with Liverpool accent, pushy, selfish but polite when speaking with standard pronunciation and irresponsible, lazy and sloppy when imitating Southern American speech. The stigmatized character of such evaluations is evident in the seeming unanimity of the respondents who generally coupled Yorkshire accent with being extravert and industrious, Cockney accent with being responsible, and considered a French person struggling to speak English polite.

\section{Conclusion}

The study data are consistent with the results of the earlier research into sociolinguistic values of English accents. What it emphasizes is an astonishing fact that in perceiving accented speech speakers of English concentrate almost exclusively on the social factors, and evaluation of the personal properties is predetermined by those. This explains why, surprisingly, no respondent in the 
experiment noticed that the speech samples were recorded by the same 2 people imitating different English language varieties. The peculiarity of oral English speech perception can only be summed up in the slogan: they are what they sound like.

The study contributes to further understanding of sociolinguistic processes taking place in the English speaking societies and its results may help developing appropriate English language user strategies by non-native speakers.

\section{Acknowledgements}

The author would like to express sincere appreciation of Evgenia Sokolova's assistance in conducting the experiment.

\section{References}

Abramova, I.E. 2009. Phonetic variation outside the natural language environment. Petrozavodsk, Petrozavodsk University Press. (In Russian)

Coupland, N. and Bishop, H. 2007. Ideologised values for British accents. Journal of Linguistics, vol.11, issue 1, 74-93.

Labov, W. 1966. The social stratification of English in New York City. Washington, D.C., Center of Applied Linguistics.

Shamina, E.A. 2011. Subjective evaluation of the phonetic representation of some national and regional varieties of the English language. In S. Androsova (ed.), Proceedings of the 1st International Conference "Phonetics without Borders", 9698. Blagoveshchensk, Russian Federation.

Shamina, E.A. 2012. On objectivity of subjective evaluation of some national and regional English accents. In L.A. Verbitskaya, N.K. Ivanova (ed.). Homo speaking: XXI century research, 150 - 155. Ivanovo, Ivanovo State University of Chemical Technology Press. (In Russian).

Wells, J.C. 1982. Accents of English, vol. 1 .Cambridge, Cambridge University Press. 